How to cite in Chicago: Montenegro Ortiz, Carlos Manuel. "Dewey as experience”. Escritos 28, no. 61 (2020): 62-77. doi: http://dx.doi.org/10.18566/escr.v28n61.a05

Date of reception: 27.09 .2020

Date of acceptance: 09.11.2020

\title{
Dewey as experience
}

\author{
Dewey como Experiencia
}

Carlos Manuel Montenegro Ortiz ${ }^{2}$

\begin{abstract}
What did John Dewey mean by the experience? Researchers of John Dewey's work (philosophers, psychologists, artists and educators, among many others) often attempt to decipher the American thinker's thesis, statements and postulates. However, specific approaches have probably become inexact when interpreting many of his concepts, even thinking that they are superficial idealism. Detailed state-of-the-art review during the past decade, in terms of the idea of experience in Dewey, makes it possible to think that this concept -although not precisely defined as that of a dictionary- can be analyzed more accurately. The last is the debate and reflection that will be open to the academic community in this paper; to clarify and, subsequently, define the concept, two fundamental and inherent aspects are presented in this document: first, the pragmatist line that addresses an epistemological framework of the idea; second, two Deweyan elements will be enlightened, these are the living organism and nature, which, as the axis of an empirical influence, are analyzed from the Vermont philosopher's perspective.

This concept also addresses three essential perspectives: biological, psychological and social, bearing in mind that, according to Dewey, real experiences occur if "meaning" comes after. Finally, an interpretative approach will answer, as possible, the question posed at the beginning of this abstract.
\end{abstract}

Keywords: John Dewey; Pragmatism; Experience; Nature; Organism; Action.

1 This paper constitutes not only a decade of research but also partial results of a doctoral theoretical-philosophical dissertation in Education, concluded at Universidad Santo Tomás, Bogotá, Colombia, in 2015, and titled: "De la Experiencia al Arte Escolar: Hacia una Educación Artística desde el Pensamiento Filosófico de John Dewey," -From Experience to School Art: Towards an Art Education from John Dewey's Philosophical Thought- (PhD diss., Universidad Santo Tomás, Bogotá, 2015), 36-87. https://repository.usta.edu.co/bitstream/handle/11634/3391/ Montenegrocarlos2015.pdf?sequence=1\&isAllowed=y. The main objective was to analyze the concepts of Art and Education, as belonging to a significant John Dewey's category called Experience. This article focuses only on the first aim, which was to clarify Dewey's Experience. As part of a non-published dissertation in Spanish, this chapter has been readapted, translated to English, and enriched with updated bibliography, as well as different readapted subtitles. The last, to make it an independent unit.

2 PhD. in Education, Universidad Santo Tomás, Colombia. M. Ed. Universidad Externado de Colombia. B. Ed. Artistic Education, CENDA, Colombia. Secondary school teacher (Music/Ethics) Secretaría de Educación del Distrito Capital, SED Bogotá-Colombia, at I.E.D. Nueva Zelandia. E-mail: cmmontenegro@educacionbogota.edu.co 


\begin{abstract}
RESUMEN
¿Qué quiso decir John Dewey cuando se refirió a la Experiencia? A menudo, los investigadores que estudian la obra de John Dewey (filósofos, psicólogos, artistas y educadores, entre muchos otros) intentan descifrar las tesis, planteamientos y postulados del pensador norteamericano. Sin embargo, su estilo personal de escritura y forma de comunicar las ideas, han impedido lograr precisión en la interpretación de muchos de sus conceptos; llegando inclusive a pensarse que son idealismos superficiales. Una revisión detallada del estado del arte realizada durante la última década, en términos del concepto de "Experiencia" en Dewey, permite pensar que dicha idea -aunque sin ser definida con exactitud de diccionario- puede ser analizada aún con mayor precisión. Y es este último precisamente, el debate de reflexión que quedará abierto a la comunidad académica, partiendo del presente artículo. Para aclarar y posteriormente definir el concepto, se presentan a continuación dos aspectos fundamentales e inherentes al mismo. Por una parte, la línea pragmatista que se aborda como marco epistemológico del concepto. Por otro, sus elementos: el organismo vivo y la naturaleza, los cuales -como ejes de una influencia empirista-, serán analizados desde la visión del filósofo de Vermont. Dicho concepto será también abordado desde tres perspectivas importantes: biológica, psicológica y social, teniendo en cuenta que -según Dewey- las experiencias reales se producirán si luego de ellas viene el "significado". Por último, mediante un enfoque interpretativo, se apuntará a responder la pregunta planteada al inicio de este resumen.
\end{abstract}

Palabras clave: John Dewey; Pragmatismo; Experiencia; Naturaleza; Organismo; Acción.

It is evident to anyone who takes a survey of the objects of human knowledge, that they are either ideas actually imprinted on the senses; or else such as are perceived by attending to the passions and operations of the mind; or lastly, ideas formed by help of memory and imagination-either compounding, dividing or barely representing those originally perceived in the aforesaid ways.

George Berkeley ${ }^{3}$

\title{
Introduction
}

\section{(Deweyan pragmatism and experience: a contextual outlook)}

$\mathrm{D}$ ewey attributed pragmatism to the American mathematician Charles Sanders Pierce, also co-founder of modern symbolic logic relation, although it is not a purely American term, but a hybrid between pragmatic and practical terms: "Kant established a distinction between pragmatic and practical. The latter term applies to moral laws that Kant regards as a priori, whereas the former term applies [...] to experience"4. Hence, merges the philosophical current of John Dewey's thought: pragmatism. The American thinker is also considered pioneer or co-founder of this current, along with Sanders Pierce and William James.

Concerning pragmatism - not just the term, as such-, Dewey stated that "the gist of the notion is that the meaning of an idea or conception lies in the consequences that flow from an existence having the

3 George Berkeley, “The principles of human knowledge", in Great Books of the Western World, Encyclopedia Britannica, Inc., ed. Robert Maynard Hutchins (Chicago: The University of Chicago, 1952), 413.

4 John Dewey, “The development of American pragmatism”, in The Later Works (Vol. 2), 1925-1927. Essays, reviews, miscellany, and the public and its problems, ed. Jo Ann Boydston (Carbondale and Edwardsville: Southern Illinois University Press, 1988), 3. 
meaning in question"5. About Peirce's position, he claimed that it was he who "used the term pragmatism to designate this view of the nature of conceptual meanings"6. According to Peirce himself: "The entire intellectual purport of any symbol consists in the total of all general modes of rational conduct which, conditionally upon all the possible different circumstances and desires, would ensue upon the acceptance of the symbol"7.

Moreover, Dewey stated that James would give his interpretation to the philosophical current of pragmatism by arguing that, rather than going to the search for the truth about a given idea, the essence of meanings prevails in this current: "this is strictly a method for determining the meaning of concepts; it is not a theory of their truth nor the relation to existence"s. In general, James defined the pragmatic method in a single sentence: "to try to interpret each notion by tracing its respective consequences"; in any case, it is not enough to emphasize here the "debt" that Dewey has with James, in terms of the pragmatist legacy that the second left the first; and that Dewey did not acknowledge so openly. ${ }^{10}$

Essentially, the term pragmatism comes from the Greek root pragma, a polysemic word; but, for the case of the present work, means "action". The latter justifies the fact that, by the end of the nineteenth century, several factors affected the solid structuring of this philosophy of action: first, the birth and subsequent development of the Industrial Revolution; second, along with the influence of continental philosophy, the prestige of two theories, as they were, and still are, Darwin's origin of species and, later, Einstein's relativity. Furthermore, as McDermott stated, Dewey's approaches to philosophy would have been purely contextual, because they always remained united to interesting cultural issues. ${ }^{11}$ Many influences permeated Dewey from interest to those subjects, such as Hegel's philosophical work or Ralph Aldo Emerson's poetry in aesthetics. ${ }^{12}$

Also, Dewey shares with Kant the idea that the ability to reason, ${ }^{13}$ which ultimately separates man from animals, has allowed him to reach higher spheres of organization and advancement, both politically and socially, as intellectually and behaviorally. ${ }^{14}$ Modern thought has made this progress: "[...] the great

5 John Dewey, "Contributions to a cyclopedia of education, Volumes 3, 4 and 5", in The Middle Works 1899-1924. (Vol.7), ed. Jo Ann Boydston (Carbondale and Edwardsville: Southern Illinois University Press, 1985), 326.

6 Dewey, "Cyclopedia of education", 326.

7 Charles Sanders Peirce, "Pragmaticism”, in The essential Peirce. Selected philosophical writings, ed. Nathan Houser (Bloomington: Indiana University Press, 1998), 356.

8 Dewey, "Cyclopedia of education", 327.

9 William James, Pragmatism (New York: Dover Publications. Inc., 1995), 18.

10 James Campbell, “John Dewey's debt to William James”, in The Oxford Handbook of Dewey, ed. Steven Fesmire (New York: Oxford University Press, 2019), 626.

11 John Joseph McDermott, The philosophy of John Dewey: the structure of experience, vol. 1 (New York: Capricorn Books GPPS, 1973), 1-325.

12 John Dewey, "From absolutism to experimentalism", in The Later Works 1929-1930. Essays (Vol. 5), ed. Jo Ann Boydston (Carbondale and Edwardsville: Southern Illinois University Press, 1988), 147-160.

13 Immanuel Kant, "The critique of pure reason", in Great Books of the Western World, Encyclopedia Britannica, Inc., trans. John Miller Dow Meiklejohn, (Chicago: The University of Chicago, 1952), 14-15.

14 John Dewey, "Ethics”, in The later works (Vol. 7), 1932, ed. Jo Ann Boydston (Carbondale and Edwardsville: Southern Illinois University Press, 1989), 146. 
achievement of the eighteen century in the intellectual development of the individual was that the human mind came to realize the part it was itself playing in the whole realm of science and conduct"15. Studies on the mind and moral allowed to see man, who, being superior in knowledge to other living beings, could exercise controlled domain over nature. Then, Dewey concluded:

This was no creation of instinct or habit; nor could it be explained in terms of sense, feeling, or impulse alone. It was the work of that more active, universal, and creative type of intelligence which we call reason [man] has the dignity of a citizen, sovereign as well as subject. As guiding and controlling his own life and that of others by the power of ideas, not of force, he has the dignity of a moral person, a moral sovereignty. He does not merely take what nature brings; he sets up ends of his own and gives them worth. ${ }^{16}$

Nevertheless, what would be that missing link in terms of Dewey's great inclination for the concept of experience and its relationship with pragmatism? Thus, what is experience? Although it should not fall into the purely schematic realm, it assumes, with certainty, the role of English empiricism, in contraposition to Kantian a priori principles. ${ }^{17}$ In that sense, Locke holds the idea that men "may attain to all the knowledge they have, without the help of any innate impressions; and may arrive at certainty without any such original notions or principles" ${ }^{18}$. Hume assigned a vital weight to perceptions, stating that the latter is stronger than the ideas about them, so that what somebody remembers about the experience of an event -or, his performance- is a faint reflection of it. ${ }^{19}$ Therefore, both Hume and Locke hold a strong preference for experience based on human understanding, and so do Berkeley, who bets for ideas "imprinted on the senses" ${ }^{20}$; and Bacon, who affirmed that "truth is not to be sought in the good fortune of any particular conjuncture of time, which is uncertain, but in the light of nature and experience, which is eternal" 21 .

Notwithstanding, such origin of the experience lies in its positioning within the empirical paradigm. Dewey partially departs from it to go beyond what the English empiricists would have raised; in other words, his distance from Locke, Bacon, Berkeley, and Hume's empiricism lies in the fact that, for the American thinker, the experience isn't just a simple collection of data and sensory information that leads to the systematization of concepts, but perhaps something more profound. An experience not only initiates with the participation of the senses (perception processes), but it has another aspect: the individual can find meaning through it and, then, incorporate it into his cognitive structure:

15 Dewey, "Ethics", 146.

16 Dewey, "Ethics", 146-47.

17 Kant, “The critique of pure reason”, 14-15.

18 John Locke, "An essay concerning human understanding", in Great Books of the Western World, Encyclopedia Britannica, Inc., ed. Robert Maynard Hutchins (Chicago: The University of Chicago, 1952), 95.

19 David Hume, "An enquiry concerning human understanding", in Great Books of the Western World, Encyclopedia Britannica, Inc., ed. Robert Maynard Hutchins (Chicago: The University of Chicago, 1952), 455-57.

20 Berkeley, "The principles of human knowledge", 413.

21 Francis Bacon, "Novum Organum”, in Great Books of the Western World, Encyclopedia Britannica, Inc., ed. Robert Maynard Hutchins (Chicago: The University of Chicago, 1952), 112. 
The senses are the organs through which the live creature participates directly in the ongoings of the world about him [...]. Experience is the result, the sign and the reward of that interaction of organism and environment which, when it is carried to the full, is a transformation of interaction into participation and communication..$^{22}$

For Dewey, every experience, even a simple one, will have characteristics, causes and consequences, and will be different from another as similar as possible. Empiricism also gives importance to the simple verification of facts to approach or define something as truth, undervaluing the experience -to wit every meaningful action- generated from a particular verification experiment. On the other hand, pragmatism will not constitute a simple verification of facts or characteristics, but refer to future or immediate consequences. In this sense, the philosopher of Vermont stated that "[...] the material of thought all comes from the past; but its purpose and direction is future..."23.

At this point, precision must be made about Dewey's take away from empiricism to achieve a closer, more instrumentalist, approach to pragmatism. Dewey concluded that "pragmatism, thus, presents itself as an extension of historical empiricism, but with this fundamental difference, that it does not insist upon antecedent phenomena but upon consequent phenomena" ${ }^{24}$. In any case, it is clear how important it was, within pragmatism, to the experimental method. This importance was not brought to extremes, but linked to moral, educational, democratic, artistic and religious issues, among many others.

\section{Elements of the experience}

According to Deweyan thinking, the presence of an experience suggests, ipso facto, an action. Interest in "movement" is then reborn; this is a theme that, even since ancient Greece, has generated extensive philosophical discussions. If everything tends towards "becoming", most likely, the world is made up of successions of experiences and, therefore, small actions. Every second of time that elapses results in a series of steps, which originate others, triggering a continuous and infinite harmony (see The Heraclitean $f l u x) .{ }^{25}$ Of course, these actions do not always constitute an experience, as they do not meet the primary requirement; that is, the meaning generation. Under Dewey's "dynamic connections", they lead to the experience consumption. ${ }^{26}$

22 John Dewey, "Art as experience", in The later works 1934 (Vol. 10), ed. Jo Ann Boydston (Carbondale: Southern Illinois University Press, 2008), 28.

23 John Dewey, “Affective thought", in The later works 1925-1927 (Vol. 2), ed. Jo Ann Boydston (Carbondale and Edwardsville: Southern Illinois University Press, 1988), 106.

24 John Dewey, "The development of American pragmatism”, 12.

25 Samuel B. Jegede, "Heraclitean flux as a philosophy of social change". International Journal of Humanities and Social Science Invention 3, no. 6 (June 2014): 43-44. http://www.ijhssi.org/papers/v3(6)/Version-4/H0364041046.pdf.

26 John Dewey, "The need for a recovery of philosophy", in The Middle Works 1899-1924 (Vol.10) Essays on Philosophy and Education 1916-1917, ed. Jo Ann Boydston (Carbondale and Edwardsville: Southern Illinois University Press, 1985), 11. 
The impulse generated by the living being -specifically the human being- towards movement is an example of the action's nature. This impulse, according to Dewey, is given to men as a first cause or "reason": "A motive, in short, is simply an impulse [...]. In fact motives are as numerous as are original impulsive activities" 27 . Once an impulse occurs, the beginning of the experience takes place; this allows the individual to find meaning in what they do, see or touch. In pragmatist terms, it refers to the quality of a given action, considering the immediate consequences. ${ }^{28}$

There are many and varied situations in which John Dewey refers to the action. From another perspective, it raises such a term from moral matters concerning human behavior and nature, more psychological than social ${ }^{29}$. This way, he associates the word with the concept of purpose; he has also called it an "endsin-view" condition, familiar to every human being or group: "Our problem now concerns the nature of ends, that is ends-in-view or aims [...] ends arise and function within action" 30 . Therefore, he partially concludes that, except in natural physical reflexes, since an individual feels the impulse to act (without experiences yet), it has a particular purpose, either out of curiosity, necessity or pleasure, among others.

The early twentieth century's scientific advances were, undoubtedly, a perfect theoretical framework for the emerging thematic axes that take part in this paper: experience, action, movement and, of course, pragmatism. When the North America of the chronological period between the last quarter of the 19th and early 20th centuries locates in mind, it is easy to imagine the icon of three geared sprockets in motion. Furthermore, if it were natural science -or rather, naturalism-, the iconographic image would be that of a monkey walking successively towards its transformation into homo sapiens-sapiens. Hence, John Dewey introduced another keyword: "the organism"31.

It implies that the organism's concept -at least in Deweyan pragmatism- is closely related to experience and, therefore, to action. In other words, if there are continuous experiences in a universe of constant movement, which in turn generates from minuscule actions, then who causes these actions? Among whom are these experiences? What are the names of those entities that continuously interact in the universe? In his naturalistic facet, Dewey called them "organisms", and, in turn, will be linked to an interaction function with the "environment". So, the organism is "the present phase of action with reference to its bearing on an ulterior phase of a function. Environment the intermediate phases as affected by the initial and as affecting by the eventual phase" ${ }^{32}$.

27 John Dewey, "Human nature and conduct", in The Middle Works 1899-1924 (Vol.14), ed. Jo Ann Boydston (Carbondale and Edwardsville: Southern Illinois University Press, 1988), 86.

28 Dewey, "Human nature and conduct", 34-35.

29 Steven Fesmire, "Dewey's independent factors in moral action", in John Dewey's ethical theory: the 1932 ethics, ed. Roberto Frega and Steven Levine (New York: Routledge Taylor \& Francis, 2020), 33-36.

30 Dewey, "Human nature and conduct", 154.

31 John Dewey, "Experience and nature", in The Later Works 1925 (Vol. 1), ed. Jo Ann Boydston (Carbondale and Edwardsville: Southern Illinois University Press, 1988), 211.

32 John Dewey, "Syllabus. Types of philosophic thought", in The Middle Works 1899-1924 (Vol.13) Essays on philosophy, education and the Orient, ed. Jo Ann Boydston (Carbondale and Edwardsville: Southern Illinois University Press, 1988), 379. 
At this point, Dewey enters a field of great complexity, referring to the fact that all organisms have a mind, which always connects to bodies, continually adapting to their environment. Dewey approaches the organism in conjunction with the concept of mind, as follows: "Every 'mind' that we are empirically acquainted with is found in connection with some organized body [...] adaptive connection: plants to air, water, sun, and animals to these things and also to plants" ${ }^{33}$. Fesmire stated: "Mind is a complex function of the doings and undergoings of encultured, embodied, historically situated organisms, continuous with physical systems"34.

Moreover, Dewey concluded by suggesting that the mind joins the body; however, both continually interact with the environment: "An animal can live only as long as it draws nutriment form its medium, finds their means of defense, and ejects into it waste and superfluous products of its own making" 35 . This implies that, according to Dewey, there would then be no mind without body or body without a mind, at least as the man possesses the status of a living organism.

On the other hand, Dewey raises nature's undeniable existence: the environment coexisting with the organism, self-actions, interactions and transactions. This nature must be understood from the category of "movement", since constant psycho-physical and physical-chemical transactions occur within it; therefore, the Heraclitean principle that everything is a continuous flux fulfills ${ }^{36}$. It is not yet possible to conceive a static nature, for everything evolves and changes in tiny proportions.

Many organisms are born to reproduce and die; even if it sounds redundant, organisms, before they were born, came from a "before", and after they died, they went to an "after". A human being is many things before birth, and many after he dies, that is why there is a continuous becoming that never stops; last is a weighty reason why nature must address the concept before analyzing many other aspects of John Dewey's thinking. All these events occur in nature, as has been previously clarified, because nature brings together many things, including processes, even in social and, specifically, educational (associated with the individual and the social). Dewey gave it great importance: "Nature is the medium of social occurrences. It furnishes original stimuli; it supplies obstacles and resources" ${ }^{37}$.

It also attaches great importance to the nature-education relationship, as a social, political and democratic phenomenon. In fact, about Dewey's democratic social experience, as being part of nature, Serrano Zamora brought up the idea that "in a socializing democracy, people can meet and share their experiences, which is a condition for the articulation of individual and collective views"38. Thus, this relationship: "was

33 Dewey, "Experience and nature", 212.

34 Steven Fesmire, John Dewey, and moral imagination: pragmatism in ethics (Bloomington: Indiana University Press, 2003), 10.

35 Dewey, "Experience and nature", 212.

36 Jegede, "Heraclitean flux", 44.

37 John Dewey, "Democracy and education”, in The Middle Works 1899-1924 (Vol.9), ed. Jo Ann Boydston (Carbondale and Edwardsville: Southern Illinois University Press, 1985), 219.

38 Justo Serrano Zamora, "Democracy and the problem of domination: a Deweyan perspective", in John Dewey's ethical theory: the 1932 ethics, ed. Roberto Frega and Steven Levine (New York: Routledge Taylor \& Francis, 2020), 201. 
thought to be the first step in ensuring this more social society. It seemed that economic and political limitations were ultimately dependent upon limitations of thought and feeling" ${ }^{39}$. And he concluded:

The first step in freeing men from external chains was to emancipate them from the internal chains of false beliefs and ideals. Social life, existing institutions were too false and corrupt to be entrusted with this work. How could it be expected to undertake it when the undertaking meant its destruction? 'Nature' must then be the power to which the enterprise was to be left [...] if the mind was a wax tablet to be written upon by objects, there were no limits to the possibility of education by means of the natural environment. ${ }^{40}$

The mastery of nature (from science) is also a critical factor in scientific development. For Dewey, this development contributes to social growth, as it becomes a synonym for progress in a society that must be appreciated, since: "We do not [...] wholly control [...] nature [...], but we are in possession of a method which enables us to forecast desirable physical changes and to set about securing them. So much is the secure result of the [current] scientific revolution" ${ }^{41}$. Likewise, it is clear to the philosopher that scientific advances link to social development: "The men who invented the stationary and locomotive steam engine, and the men who have since then harnessed both steam and electricity to all sorts of ends have produced social changes"42.

The term nature derives from the Greek physis, which also means "to grow", and the Latin (same word as the former), meaning "to be born". From this, Aristotle would have defined the nature of one thing as such thing in its most complete growth or, in other words, in its ultimate realization..$^{43}$ In turn, Dewey relied on the Aristotelian analogy that "nature is an artist that works from within instead of from without, [then], like other artists, nature first possesses the forms which it afterwards embodies" ${ }^{44}$. Consequently, it raises three apparent characteristic aspects of this nature: (i) "it is implied that some natural events are endings whether enjoyed or obnoxious, which occur, apart from reflective choice and art, only casually, without control"45. (ii) "Events, being events and not rigid and lumpy substances, are ongoing and hence as such unfinished, incomplete, indeterminate" ${ }^{46}$. (iii) "Regulation of ongoing and incomplete processes in behalf of selected consequences implies that there are orders of sequence and coexistence involved" ${ }^{47}$. To get closer to a definition of nature, Dewey raised the concept of organic action: "The action called organic is not just that of internal structures; it is an integration of organic-environmental connections" ${ }^{38}$.

39 Dewey, "Democracy and education", 98

40 Dewey, "Democracy and education", 98-99.

41 John Dewey, "Progress", in The Middle Works 1899-1924 (Vol.10) Essays on philosophy and education 1916-1917, ed. Jo Ann Boydston (Carbondale and Edwardsville: Southern Illinois University Press, 1985), 237.

42 Dewey, "Progress", 237.

43 Dewey, "Cyclopedia of education", 287.

44 Dewey, "Experience and nature", 79.

45 Dewey, "Experience and nature", 126.

46 Dewey, "Experience and nature", 126-27.

47 Dewey, "Experience and nature", 127.

48 Dewey, "Experience and nature”, 213. 
All experience has a biological meaning (related to the physical-chemical processes of the organism and its environment), a psychological sense (i.e. individual, own), and a social sense (from the organism to and from its peers). ${ }^{49}$ Consequently, every experience has a meaning; therefore, if there is no such thing as the latter, the experience would be nothing more than a simple feeling. Both in one and the other, a sense related to survival, which is not only at the organic level but also from the survival of culture in general (call it survival of languages, customs and symbols), should be emphasized. Then, Dewey's experience culminates with a more philosophical-anthropological than purely epistemological approach, even more than merely. Henceforth, the above concept, which begins as a biological process, will be a much more sublime social issue.

\section{Experience: between the biological and the social}

From a biological perspective, Dewey sees the experience, at first instance, as a "living function"; that is a set of tensions between the organism and its environment but, in a unified, not separated way. Thompson and Piso added that "the form of the organism/environment is exhibited widely. Staying within biology, a species or breeding population is situated within an environment [...]. Moving to social behavior, the reproducibility of group identity hangs upon being environed in a manner that generates situatedness and its attendant mechanisms of control" ${ }^{50}$. For example, paradoxically, "an animal must be alive in order to struggle to live" ${ }^{11}$. As Dewey stated, this confirms that the functions (which are nothing more than habits in operation) make an organism belong to nature and go through it.

It should be noted that the function is somehow a kind of coordinated balance of movement: every motor activity of the organism has a complementary mechanism; that is what happens, for example, with the body's antagonistic muscles, which retract and expand. ${ }^{52}$ Also, the arms' ability to move: while a muscle allows one arm to rise, another -the antagonistic- enables it to lower. The same situation can be breathing: the diaphragm and its antagonist cause the lungs' retraction and expansion that allow air to be taken and expelled.

From another perspective, without ignoring the biological, Dewey proposed another joint facet, at least from human experience, the social: "life is of the social kind. It is equally fallacious to ignore the biological aspect and use it to determine the subject matter as the narrower form of behaviorism does. By social is denoted such things as communication, participation, sharing, communion" ${ }^{53}$. Dewey raised some essential aspects around which the theme of experience in social perspective revolves, among others:

1. The individual interacts with its nature and transforms it. For example, concerning the transformation of interdependencies, when tools and language come into play, these: "get a meaning. They become economic and legal; distributions of occupations -the division of labor about shared consequences;

49 Dewey, "Syllabus. Types of philosophic thought", 377-82.

50 Paul B. Thompson and Zachary Piso, "Dewey and environmental philosophy", in The Oxford Handbook of Dewey, ed. Steven Fesmire (New York: Oxford University Press, 2019), 722.

51 Dewey, "Syllabus. Types of philosophic thought", 377.

52 Dewey, "Syllabus. Types of philosophic thought", 377-78.

53 Dewey, "Syllabus. Types of philosophic thought", 382. 
organizations of protection, defense, and attack, with rules of conduct" 54 . The last denotes evidence to affirm that after a pseudo experience, comes true meaning, with which the experience is completed or consummated. In terms of "art", with some specific features, such as energies and works of art, , $^{55}$ recent studies have found that "a quick experience is not necessarily a complete experience, and its approach is not intended to restrict aesthetics to superficiality, but rather to free it from the idealistic imprisonment to which it had hither to been subjected"56. Hence, Hubert not only defended the idea that -as shown at the beginning-, Dewey's experience should not be considered as a mere idealism, but also affirmed that experience -in this case, aesthetic- should not be separated from social and individual life ${ }^{57}$.

2. "In addition to these transformations, community-life introduces new functions: fine art and reflective behavior -thinking, inference" 58 . In this regard, Dewey added three crucial aspects of this numeral: first, the rhythmic sense as a present human and animal facet; hazard signals, for example, are a type of pantomime among animals, as well as other pleasant activities such as dance. Second, personal decoration or ornamentation, it appears in humans of all regions, tribes or civilizations (see Shusterman's concept of somaesthetics) ${ }^{59}$. Third, free languages (expression language), such as storytelling, myths and legends.

3. "Language and signs" ${ }^{\prime \prime}$. At this point, Dewey underlines everything concerning gestures, cries, postures and all sorts of external demonstrations of feelings. Also called "expressive", these acts are another example of consummate events, previously elaborated; that is, they have already acquired some meaning. Unlike animals, acts of signaling in humans become "signs" thanks to language; therefore, these events are more complex, since they generate "understanding" itself: "A, acts so as to get $B$ to act in a way which is a means of both $A$ and $B$ engaging in a common or shared act" 61 . Here lies the differential factor between the animal and the human; A's action concerning B, or vice versa, has meaning. In other words, there is already a sign (presence of language), and not merely, as Dewey says, a stimulus. Consequently, human beings possess the ability to do introspection; ${ }^{62}$ that is, they are able to speak to themselves in the same way that they communicate with others through a "silent language". That is what constitutes a rational discourse for Dewey: "a tight connection between self and interest"63.

54 Dewey, "Syllabus. Types of philosophic thought", 382.

55 See the concept of Dewey's aesthetic experience at Carlos Manuel Montenegro Ortiz, "Arte y experiencia estética: John Dewey", Revista Nodo 9, no. 17 (2014): 97-99. http://csifesvr.uan.edu.co/index.php/nodo/article/viewFile/362/262.

56 Laura Elizia Haubert, "Notes on aesthetic experience and everyday experience in John Dewey", Cognitio-Estudos: Revista Electrônica de Filosofia 16, no.2 (2019): 231. DOI: 10.23925/1809-8428.2019v16i2p222-232.

57 Haubert, "Notes on aesthetic experience", 225-226.

58 Dewey, "Syllabus. Types of philosophic thought", 382.

59 Richard Shusterman, Body Consciousness: a philosophy of mindfulness and somaesthetics (New York: Cambridge University Press, 2008), 196-97.

60 Dewey, "Syllabus. Types of Philosophic Thought", 383.

61 Dewey, "Syllabus. Types of philosophic thought", 383.

62 Dewey, "Syllabus. Types of philosophic thought", 392.

63 Matteo Santarelli, "Psychology, moral theory, and politics", in John Dewey's ethical theory: The 1932 Ethics, ed. Roberto Frega and Steven Levine (New York: Routledge Taylor \& Francis, 2020), 233. 
From a psychological perspective, Dewey clarifies the difference between the experiencer and the experience; however, the latter involves everything experienced. ${ }^{64}$ In this sense, the experiencer would be the "how", that is, the mode or method of experience. Gregory Pappas reinforced Haubert's ${ }^{65}$ idea by affirming that "genuine empiricism in philosophy entails that no matter how abstract and remote our philosophical speculations might turn out to be, we need to start from and return to everyday situational lived experience" 66 . The psychological will deal with the human being's affairs, from an individual point of view, but considering that such individuality affects and is affected by society. In this regard, Pappas would say that "the functional distinction between experiencing -the how- and the subject matter experienced -the what- allows a pragmatist to recover the normative ethical issue of how one should live in a way that is consistent with her philosophical approach" ${ }^{67}$. Introspection plays a vital role in the psychological aspect, since it is a mental and individual trait typical of the man and affects the social environment or -if not- can be affected by it.

It is vital in the psychological aspect of the experience, to keep in mind that, as already mentioned, not all the qualities of the "experiencing" (carrying out the experience) are necessarily cognitive. There are qualities of experience, non-cognitive, such as social quality, religious quality or aesthetics, among others, which, although they occasionally fall into the cognitive, are not at their core. Furthermore, as has been implied so far, cognitive aspects will always be subject to non-cognitive aspects or, in other words, the intellectual quality will have passed first through sensory quality. About this aspect, and focused on moral issues, Dreon highlighted Dewey's idea that "any reflective kind of experience is anchored in primarily qualitative, affective, or aesthetic interactions with the natural as well as naturally social environment" ${ }^{68}$.

Indeed, Dewey refers to the following tenet "each individual has something that is unique or irreplaceable [...] principle of individuality" ${ }^{\prime \prime}$. As aspects of individuality, there is also the psychology of meaning, that is, the related to what has now been called mental operations or even competences: comparison, conceptualization, abstraction and generalization. On the other hand, the philosophical problem persists -the body and the relationship generated in the field of experience-. In Dewey's words: "Mind signifies both the system of meanings and the concrete set of existences through which meanings are developed, sustained, realized and developed"70.

The individual (the living organism) will always be in contact with their exterior, call it environment or social environment. In terms of habits, as a vital social/psychological aspect of moral, Madelrieux added: "From a biopsychological standpoint, habit is the natural basis of moral conduct (even if habits are social

64 Dewey, "Syllabus. Types of philosophic thought”, 392-93.

65 Haubert, "Notes on aesthetic experience", 225-226.

66 Gregory Fernando Pappas, "The starting point of Dewey's ethics and sociopolitical philosophy”, in The Oxford Handbook of Dewey, ed. Steven Fesmire (New York: Oxford University Press, 2019), 236.

67 Gregory Fernando Pappas, John Dewey's ethics: democracy as experience (Bloomington: Indiana University Press, 2008), 71.

68 Roberta Dreon, “Dewey's fully embedded ethics”, in John Dewey's ethical theory: The 1932 Ethics, ed. Roberto Frega and Steven Levine (New York: Routledge Taylor \& Francis, 2020), 210.

69 John Dewey, "Individuality in education", in The Middle Works 1899-1924 (Vol.15) Essays on Politics and Society 1923-1924, ed. Jo Ann Boydston (Carbondale and Edwardsville: Southern Illinois University Press, 1988), 170-71.

70 Dewey, "Syllabus. Types of philosophic thought", 393. 
in content and depend on cultural environments)"71. This contact translates into numerous experiences that occur through time and space and can be synthesized through minuscule actions. Here is a list of verbs (actions) proposed by Dewey that picture many of these experiences, since these contain smaller ones (can be called sub-actions); the author considered them "categories" of experience. In the first group are greeting, rejecting, receiving, admitting, taking, sustaining, affirming, recognizing, denying, doubting and stopping. In the second group are start, follow, exalt, rise, search, look, hunt, desire, ask, propose, climb, happen and return. Of course, many other sub-actions would generate an example of experience from these and others.

Behind every experience to be regarded not as a mere feeling, there is a "meaning"; when it concludes, not only there is something given, but also something to receive. Dewey believed that passive experience (as a test or experiment: trial and error) becomes a simple single-pole sensation or activity, whereas from an "active" point of view that involves two poles, the meaning appears as follows:

Mere activity does not constitute experience. It is dispersive, centrifugal, dissipating. Experience as trying involves change, but change is meaningless transition unless it is consciously connected with the return wave of consequences which flow from it. When an activity is continued into the undergoing of consequences, when the change made by action is reflected back into a change made in us, the mere flux is loaded with significance. We learn something. ${ }^{72}$

The above quote is illustrated by Dewey, with the typical example of the child and the candle: when a child approaches their finger to the candle and burns with the fire, it is said that there has been a test or a simple experimental action of trial and error. Now, when that same child suffers from consequent pain, he knows that putting their finger on the fire "means" burning. It is not the same as the simple action in which firewood consumes in the fire, for if a piece of wood does not possess thought -much less the ability to extract meaning-, the latter (the piece of wood) will never have "lived" the experience. ${ }^{73}$

Finally, the American thinker underlines the experience's social aspect by presenting its relationship with language and communication. Meanings can be "referral" when they're present in consciousness and represent things as means or "imminent", which are simply the consummation of the experience, that is, in its final phase. In this sense, there are reciprocal relationship means-consequences. In turn, "referential meanings are indicative and implicative, according as meaning is found in a natural event or in an artificial sign -content of proper or common noun-" ${ }^{\prime 7}$. As a natural event, stimuli and perceptions are understood; as well as artificial signs, conceptualizations, notions, words, terms, icons or any language and communication aspect. Therefore, signals can be denotative when they point or indicate; on the other hand, they would be connotative when they are the object's direct essence or idea ${ }^{75}$.

71 Stéphane Madelrieux "Moral holism and the pragmatist character", in John Dewey's ethical theory: The 1932 Ethics, ed. Roberto Frega and Steven Levine (New York: Routledge Taylor \& Francis, 2020), 68.

72 Dewey, "Democracy and education", 146.

73 Dewey, "Democracy and education", 146.

74 Dewey, "Syllabus. Types of philosophic thought", 389.

75 Dewey, "Syllabus. Types of philosophic thought", 383-393. 
There are inner meanings and external meanings ${ }^{76}$; the first are reflective, and the last are cognitive. These, Dewey stated, should not be confused, because the (external) data are not merely meanings, but inherited meanings and, in this sense, requires: "an idea-plan, hypothesis, theory -to direct selection of material as data-. But the purpose is not to complete this idea, with which we set out, but to discover and develop some meaning which will be sustained by the fact of the case"77. The social origin and the very meaning of the meanings cannot overlook: "The individualistic (psychological) and abstract logistic theories of meaning both spring from ignoring the fact that in human relations interaction becomes communication terminating in shared consummatory objects" 78 .

\section{So, what is experience? (Conclusion)}

Then, how to clarify John Dewey's concept of experience? The aspects widely developed so far intend to summarize ideas to achieve a concrete clarification. As a conclusion of the previous section, the experience for Dewey is:

A compound phenomenon, while it involves not only many more phenomena but also characters. Therefore, experience may have multiple facets, states, or shapes. In other words, experience, from John Dewey's perspective, is not "one" single thing. Nor is it a static concept. Therefore, the very idea that experience has a beginning and end, in addition to the approach that the end becomes the beginning of a new one, suggests the time factor is critical in its dynamic character. Hence, the space factor comes into play, which corroborates that character.

From this, when talking about experience, a new scenario emerges; this is, nature. The latter is understood as the complex set of organisms, environment and even experiences; this is given in by the movement (through action). The last, considering that everything is moving in a pragmatic sense, and that experience is never static, never stops, and occurs in time and space. To conclude, there is a relationship between this and the historical "becoming" (flux) raised by Heraclitus. That idea of ancient Greece asserts that everything comes from something, happens, and then, continues. It cannot be said, for example, that a tree is born, grows, reproduces and dies, because, when it dies, it gives way to a series of new events that allow to start a new process. Therefore, "becoming" is the constant flow from one point towards another that never comes back; it never stops (it should not be said that experience is pure "becoming" or "flux", but it does partially relate to a philosophical approach). In Jackson's words, Deweyan experience "exists in time, and it changes over time, which means it has a history that can be described in narrative terms or in other language that seeks to convey the changing nature another language" 79 .

76 See Dreon, "Dewey's fully embedded ethics" about "affective meanings of experience", 210.

77 Dewey, "Syllabus. Types of philosophic thought", 390.

78 Dewey, "Syllabus. Types of philosophic thought", 390.

79 Philip Jackson, "If we take Dewey's aesthetics seriously, how would the arts be taught?" in The New Scholarship on Dewey, ed. Jim Garrison (Dordrecht: Kluwer Academic Publishers, 1995), 25-34. 
If experience is based on the action, which generates movement, then there are different types of action, depending on the degree of complexity: the most straightforward action, or self-action, which is generated within an specific entity (for Dewey, the organism); another more complex action -or interaction- in which two organisms (or more) relate without either party relying on the other; and the more complex, the transaction, that involves two or more entities that affect each other. Even the plane of action, in any of its facets, can intervene all beings of nature.

The experience will depend on significance. If the man is the only animal that possesses the capacity to think and build meanings, then experience is given at the human's level. The rest are nothing but actions or, if they can be called so, pseudo-experiences. Then, not everything that a man does is experience; if it does not perceive the meaning from transactions or interactions, any experience is incomplete (or not consummated), leaving the superficial plane of action and perception. It is discussed why actions and pseudo-experience, although not easy to become, are closer to it than authentic experience; the latter is also linked to biological phenomena, as it occurs entirely in a man's organism. However, in non-rational animals, plants, or inert beings, experience is not completed or consummated; nevertheless, it does not mean that they have not been part of the human experience.

In this regard, it would be essential to discuss how experience is an event that involves one or more beings in the environment, which are not necessarily human, and only make sense when they become a part of a man. For example, when a man ingests his food, he is coming into direct contact with it and, therefore, if he can reason about its nutritional value, he consumes an experience in a Deweyan sense, taking into account that there is a presence of meaning. Now, the digestion process would come. There are several events, involuntary movements, and chemical and physical reactions inside the body, which do not necessarily make up experiences with each other; however, these events are part of the accomplished experience. It could be inferred that experience -Deweyan- is only human, even if it shows situations that highlight action and movement; nevertheless, Dewey clarified that experience is a matter "of the interaction of living creatures with their environments; human experience being what it is because human beings are subject to the influences of culture, including use of definite means of intercommunication" ${ }^{80}$.

Consequently, the experience, being biological from a human perspective, is also linked to psychological and social factors, because, even if the man lived in austerity, he would have been given birth, as well as he could reproduce himself. This makes him, ipso facto, a social being. The association's need is almost an instinct inherited from non-rational animals (look at ants' behavior, for instance, among many other animals. They are organized and work together, generating a climate of cooperation, if only instinctively).

Experience involves both chemical and physical properties. If there is given any thought about everything that happens for a fraction of the time in which an experience consummates, there would be an extensive list of chemical reactions, displacements, reasoning, physical wear, adaptations of the organism, imbalances and balances (it is the case of the food, as mentioned above, and the digestive process). Also, what closes or consumes one experience would, then, become the beginning of another; in this sense, there can be seen two peculiarly combined optics: a "passive", or merely practical matter, an essential factor of the empirical paradigm (as a test, essay or experiment, in the literal sense of the word).

80 John Dewey, “Experience, knowledge, and value: a rejoinder", in The Later Works 1925-1953 (Vol. 14) Essays, Reviews, and Miscellany 1939-1941, ed. Jo Ann Boydston (Carbondale: Southern Illinois University Press, 1989 ), 15. 
Additionally, another "active"; that is, as "suffering", as "when we experience something we act upon it, we do something with it; then we suffer or undergo the consequences. We do something to the thing and then it does something to us in return: such is the peculiar combination"81.

\section{Bibliography}

Bacon, Francis. "Novum Organum". In Great Books of the Western World, Encyclopedia Britannica, Inc., edited by Robert Maynard Hutchins, 105-195. Chicago: The University of Chicago, 1952.

Berkeley, George. "The principles of human knowledge". In Great Books of the Western World, Encyclopedia Britannica, Inc., edited by Robert Maynard Hutchins, 399-444. Chicago: The University of Chicago, 1952.

Campbell, James. "John Dewey's debt to William James". In The Oxford Handbook of Dewey, edited by Steven Fesmire, 615-628. New York: Oxford University Press, 2019. https://doi.org/10.1093/oxfordhb/9780190491192.013.22

Dewey, John. "Affective thought". In The Later Works 1925-1927 (Vol. 2), edited by Jo Ann Boydston, 104-110. Carbondale and Edwardsville: Southern Illinois University Press, 1988.

Dewey, John. “Art as experience". In The Later Works 1934 (Vol. 10), edited by Jo Ann Boydston, 1-459. Carbondale: Southern Illinois University Press, 2008.

Dewey, John. "Contributions to a cyclopedia of education, volumes 3, 4 and 5". In The Middle Works 1899-1924. (Vol.7), edited by Jo Ann Boydston, 207-365. Carbondale and Edwardsville: Southern Illinois University Press, 1985.

Dewey, John. "Democracy and education". In The Middle Works 1899-1924 (Vol.9), edited by Jo Ann Boydston, 1-384. Carbondale and Edwardsville: Southern Illinois University Press, 1985.

Dewey, John. "Ethics". In The Later Works (Vol. 7), 1932, edited by Jo Ann Boydston, 1-509. Carbondale and Edwardsville: Southern Illinois University Press, 1989.

Dewey, John. "Experience and nature". In The Later Works 1925 (Vol. 1), edited by Jo Ann Boydston, 1-409. Carbondale and Edwardsville: Southern Illinois University Press, 1988.

Dewey, John. "Experience, knowledge, and value: a rejoinder". In The Later Works 1925-1953 (Vol. 14) Essays, Reviews, and Miscellany 1939-1941, ed. Jo Ann Boydston, 3-90. Carbondale: Southern Illinois University Press, 1989.

Dewey, John. "From absolutism to experimentalism". In The Later Works 1929-1930. Essays (Vol. 5), edited by Jo Ann Boydston, 147-160. Carbondale and Edwardsville: Southern Illinois University Press, 1985.

Dewey, John. "Human nature and conduct". In The Middle Works 1899-1924 (Vol.14), edited by Jo Ann Boydston, 1-236. Carbondale and Edwardsville: Southern Illinois University Press, 1988.

Dewey, John. "Individuality in education". In The Middle Works 1899-1924 (Vol.15) Essays on Politics and Society 1923-1924, edited by Jo Ann Boydston, 170-179. Carbondale and Edwardsville: Southern Illinois University Press, 1988.

Dewey, John. "Progress". In The Middle Works 1899-1924 (Vol.10) Essays on Philosophy and Education 1916-1917, edited by Jo Ann Boydston, 234-243. Carbondale and Edwardsville: Southern Illinois University Press, 1985.

Dewey, John. "Syllabus. Types of philosophic thought". In The Middle Works 1899-1924 (Vol.13) Essays on philosophy, education, and the orient, edited by Jo Ann Boydston, 49-95. Carbondale and Edwardsville: Southern Illinois University Press, 1988.

Dewey, John. "The development of American pragmatism”. In The Later Works (Vol. 2), 1925-1927. Essays, reviews, miscellany, and the public and its problems, edited by Jo Ann Boydston, 3-21. Carbondale and Edwardsville: Southern Illinois University Press, 1988.

Dewey, John. "The need for a recovery of philosophy". In The Middle Works 1899-1924 (Vol.10) Essays on Philosophy and Education 1916-1917, edited by Jo Ann Boydston, 3-48. Carbondale and Edwardsville: Southern Illinois University Press, 1985.

81 Dewey, "Democracy and education", 146. 
Dreon, Roberta. "Dewey's fully embedded ethics". In John Dewey's ethical theory: the 1932 ethics, edited by Roberto Frega and Steven Levine, 210-228. New York: Routledge Taylor \& Francis, 2020.

Fesmire, Steven. "Dewey's independent factors in moral action". In John Dewey's ethical theory: the 1932 ethics, ed. Roberto Frega and Steven Levine, 33-59. New York: Routledge Taylor \& Francis, 2020. https://doi. org/10.4324/9780429259869-3

Fesmire, Steven. John Dewey and moral imagination: pragmatism in ethics. Bloomington: Indiana University Press, 2003.

Hume, David. "An enquiry concerning human understanding". In Great Books of the Western World, Encyclopedia Britannica, Inc., edited by Robert Maynard Hutchins, 445-509. Chicago: The University of Chicago, 1952.

Haubert, Laura Elizia. "Notes on aesthetic experience and everyday experience in John Dewey". Cognitio-Estudos: Revista Electrônica de Filosofia 16, no. 2 (July-December 2019): 222-232. https://doi.org/10.23925/1809$\underline{8428.2019 v 16 i 2 p 222-232}$

Jackson, Philip. "If we take Dewey's aesthetics seriously, how would the arts be taught?". In The new scholarship on Dewey, edited by Jim Garrison, 25-34. Dordrecht: Kluwer Academic Publishers, 1995. https://doi. org/10.1007/978-94-011-0071-7 3

James, William. Pragmatism. New York: Dover Publications. Inc., 1995.

Jegede, Samuel B. "Heraclitean flux as a philosophy of social change". International Journal of Humanities and Social Science Invention 3, no. 6 (June 2014): 41-46. http://www.ijhssi.org/papers/v3(6)/Version-4/H0364041046.pdf.

Kant, Immanuel. “The critique of pure reason”. In Great Books of the Western World, Encyclopedia Britannica, Inc. Translated by John Miller Dow Meiklejohn, 1-250. Chicago: The University of Chicago, 1952.

Locke, John. "An essay concerning human understanding". In Great Books of the Western World, Encyclopedia Britannica, Inc., edited by Robert Maynard Hutchins, 93-395. Chicago: The University of Chicago, 1952.

Madelrieux, Stéphane. "Moral holism and the pragmatist character". In John Dewey's ethical theory: the 1932 ethics, edited by Roberto Frega and Steven Levine, 61-79. New York: Routledge Taylor \& Francis, 2020. https://doi. org/10.4324/9780429259869-5

McDermott, John Joseph. The philosophy of John Dewey: the structure of experience (vol. 1). New York: Capricorn Books, GPPS, 1973.

Montenegro Ortiz, Carlos Manuel. “Arte y experiencia estética: John Dewey”, Revista Nodo, 9, no. 17 (July-December 2014): 95-105. http://csifesvr.uan.edu.co/index.php/nodo/article/viewFile/362/262.

Montenegro Ortiz, Carlos Manuel. "De la experiencia al arte escolar: hacia una educación artística desde el pensamiento filosófico de John Dewey”. PhD diss., Universidad Santo Tomás, Bogotá, 2015. https://repository. usta.edu.co/bitstream/handle/11634/3391/Montenegrocarlos2015.pdf? sequence=1 \&isAllowed=y.

Pappas, Gregory Fernando. John Dewey's ethics: democracy as experience. Bloomington: Indiana University Press, 2008.

Pappas, Gregory Fernando. “The starting point of Dewey's ethics and sociopolitical philosophy”. In The Oxford Handbook of Dewey, edited by Steven Fesmire, 235-253. New York: Oxford University Press, 2019. https://doi. org/10.1093/oxfordhb/9780190491192.013.7

Peirce, Charles Sanders. "Pragmaticism". In The essential Peirce. Selected philosophical writings, ed. Nathan Houser (Bloomington: Indiana University Press, 1998), 331-474.

Santarelli, Matteo. "Psychology, moral theory, and politics". In John Dewey's ethical theory: the 1932 ethics, edited by Roberto Frega and Steven Levine, 229-247. New York: Routledge Taylor \& Francis, 2020.

Serrano Zamora, Justo. "Democracy and the problem of domination: a Deweyan perspective". In John Dewey's ethical theory: the 1932 ethics, edited by Roberto Frega and Steven Levine, 184-208. New York: Routledge Taylor \& Francis, 2020.

Shusterman, Richard. Body consciousness: a philosophy of mindfulness and somaesthetics. New York: Cambridge University Press, 2008. https://doi.org/10.1017/CBO9780511802829

Thompson, Paul B., and Piso, Zachary. "Dewey and environmental philosophy”. In The Oxford Handbook of Dewey, edited by Steven Fesmire, 713-732. New York: Oxford University Press, 2019. 